\title{
Local influences of geothermal anomalies on permafrost distribution in an active volcanic island (Deception Island, Antarctica)
}

\author{
G. Goyanes ${ }^{\text {a,* }}$, G. Vieira ${ }^{\text {b }}$, A. Caselli ${ }^{\text {c }}$, M. Cardoso ${ }^{\text {b }}$, A. Marmy ${ }^{\text {d }}$, F. Santos ${ }^{\text {e }}$, I. Bernardo ${ }^{\text {e }}$, C. Hauck ${ }^{\text {d }}$ \\ a Instituto de Estudios Andinos “Don Pablo Groeber” (UBA-CONICET), Departmento de Ciencias Geológicas, Universidad de Buenos Aires, Int. Güiraldes 2160, Ciudad Universitaria, \\ Pab.2. C1428EHA, Buenos Aires, Argentina \\ b Centro de Estudos Geográficos, Universidade de Lisboa, Alameda da Universidade, 1600-214 Lisbon, Portugal \\ c Universidad de Río Negro, Isidro Lobo y Belgrano, 8332 Gral. Roca, Río Negro, Argentina \\ d Alpine Cryosphere and Geomorphology Group, University of Fribourg, Chemin du Musée 4-1700 Fribourg, Switzerland \\ e Centre of Geophysics, IDL, University of Lisbon, Alameda da Universidade, 1600-214 Lisbon, Portugal
}

\section{A R T I C L E I N F O}

\section{Article history:}

Received 25 March 2013

Received in revised form 24 March 2014

Accepted 7 April 2014

Available online 13 April 2014

\section{Keywords:}

Permafrost

Geothermal Anomaly

Active Volcano

Deception Island

South Shetlands

Antarctica

\begin{abstract}
A B S T R A C T
This study aims at understanding the spatial distribution and characteristics of the frozen and unfrozen terrain in an alluvial fan on Deception Island, which is an active strato-volcano located in the Bransfield Strait (South Shetland Islands) with recent eruptions in 1967, 1969 and 1970. The alluvial fan is dominated by debris-flow, run-off and rock fall processes and permafrost occurs in several parts in the vicinity of anomalous geothermal heat flux. The aim is to assess the ways volcanic activity controls permafrost development and associated geomorphic dynamics using shallow subsurface, surface and air temperature measurements as well as thaw depth and electrical resistivity tomography (ERT) surveys.

Results show a temperature increase with depth in the lower part of the fan reaching $13{ }^{\circ} \mathrm{C}$ at $0.80 \mathrm{~m}$ depth, without the presence of permafrost. The shallow borehole located at this site showed a stable thermal stratification all year-round, with only the upper $0.20 \mathrm{~m}$ reacting to meteorological forcing. In the upper part of the alluvial fan and debris cones, c. $100 \mathrm{~m}$ from the coast, frozen ground is present at c. $0.70 \mathrm{~m}$ depth. There, the shallow borehole shows a good coupling with air temperatures and the thermal regime favours the presence of permafrost. ERT shows the lowest resistivity values in the lower part of the alluvial fan and a highly resistivity zone in the upper sector of the fan and in the debris cones. These large variations in resistivity mark the presence of a saline water wedge from the sea into the fan, reaching frozen ground conditions about $100 \mathrm{~m}$ inland. It can be shown that the volcano-hydrothermal activity only inhibits frost development very locally, with frozen ground conditions occurring about $100 \mathrm{~m}$ away.
\end{abstract}

(c) 2014 Elsevier B.V. All rights reserved.

\section{Introduction}

The western Antarctic Peninsula is one of the regions in the World with the strongest climate warming trend, with an increase of c. $+3.4{ }^{\circ} \mathrm{C}$ in the mean annual air temperatures since 1950 (Turner et al., 2005, 2007). While glaciers and ice-shelves are being monitoring to evaluate the effects of climate change, permafrost, an important component of the Antarctic cryosphere has been largely neglected and only recently started to be monitored systematically (Vieira et al., 2010; Bockheim et al., 2013). Permafrost, which occupies only $0.36 \%$ $\left(49,800 \mathrm{~km}^{2}\right)$ of the Antarctic region, is present beneath virtually all ice-free terrain, except at the lowest elevations of the maritime Antarctic and sub-Antarctic islands (Ramos et al., 2012). Permafrost occurrence has been confirmed in the South Shetlands by many authors

\footnotetext{
* Corresponding author at: Int. Güiraldes 2160, Ciudad Universitaria, Pab.2 C1428EHA, Buenos Aires, Argentina. Fax: + 5401145763400.

E-mail address: goyanes@gl.fcen.uba.ar (G. Goyanes).
}

(Ramos et al., 1989; Serrano and López-Martinez, 2000; Hall, 2002; Bockheim et al., 2007; Vieira et al., 2010, among others), who also noted several permafrost-free sites at low altitude. Due to a tectonic setting of Bransfield strait opening (rift aperture), some of these sites show a high geothermal heat flux, such as Bridgeman, Penguin and Deception islands (De Rosa et al., 1995; Gràcia et al., 1996), inhibiting the development of large thickness of permafrost.

In recent decades there has been a growing interest in volcano-ice systems, mainly by those involved on research on the similarity between the terrestrial and Martian processes. Four important themes drive this trend: volcano hazard awareness and prevention, the Pleistocene global climate record, potential feedbacks between deglaciation and volcanism, and Martian geoscience research (Smellie and Chapman, 2002; Edwards et al., 2009). Despite this, only a few works refer to the interaction between permafrost and terrains under geothermic effects, both in what relates to spatial variability of ground thermal state, but also on the seasonal behaviour of the ground thermal regime. Such studies could be relevant for understanding the 


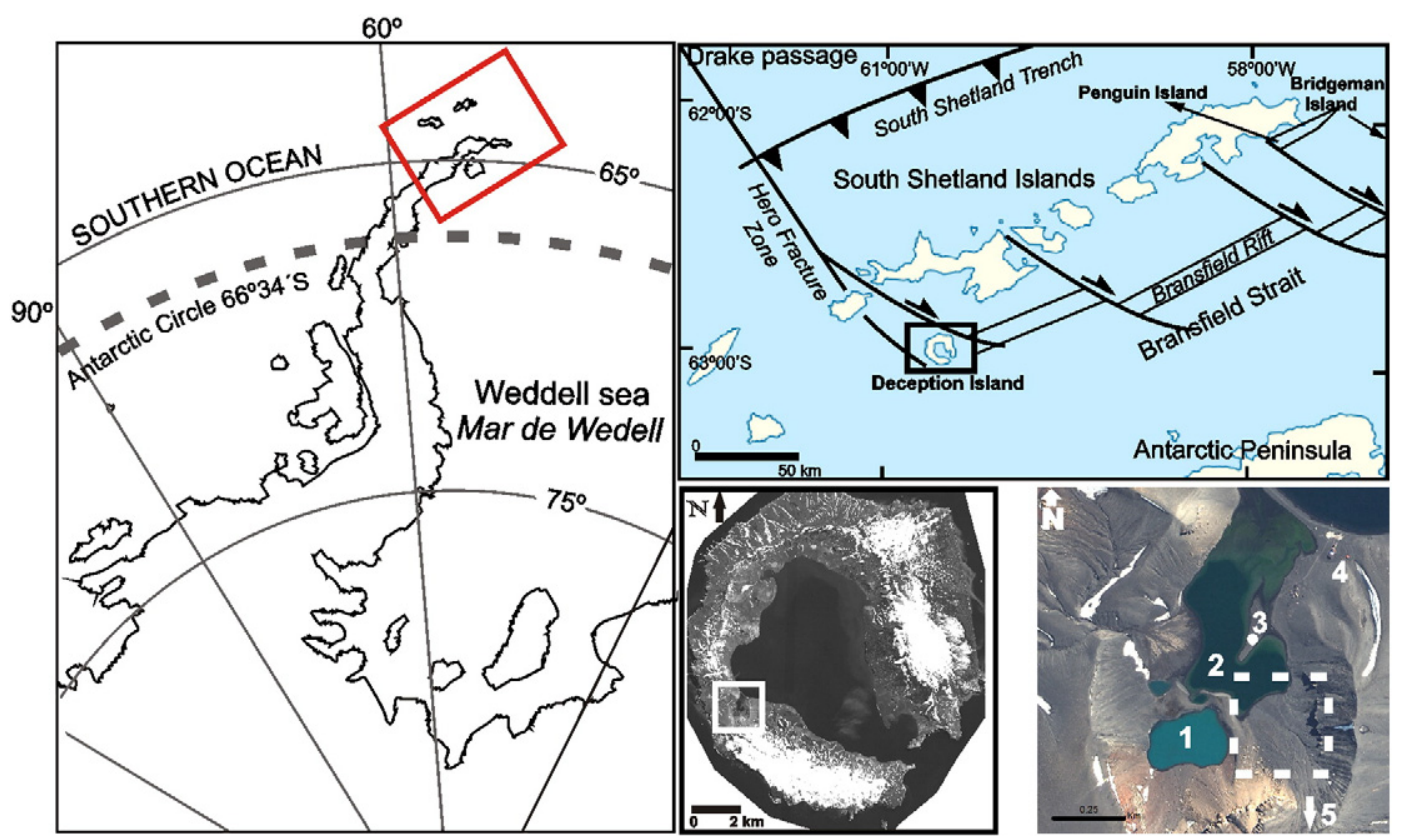

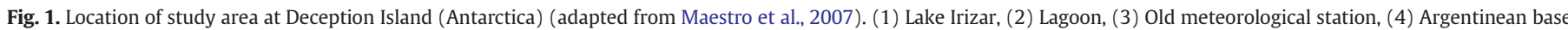
Decepción, (5) Mount Irizar. The area enclosed in the dotted line is the Irizar alluvial fan detailed study area.

mechanism of lahars caused by permafrost melt, thermokarst collapse features, the geomorphic dynamics associated with such areas, but also to investigate adaptations of extremophiles.

On Earth, ice-permafrost-volcano interactions are common at high altitude or latitude stratovolcanoes (Iceland, Andes, Alaska, Kamchatka peninsula, Antarctica, among others) (Kellerer-Pirklbauer, 2007).
Bleick et al. (2013) mention signs of abnormal heat flow in the summit crater of Redoubt Volcano (Alaska) preceding the 2009 eruption and triggering melting and ablation of Redoubt's glaciers and a variety of morphological changes, like the deposition from a large amount of debris flows. Tormey (2010) showed how glacial melting and magmatic activity have triggered landslides and sector collapses at

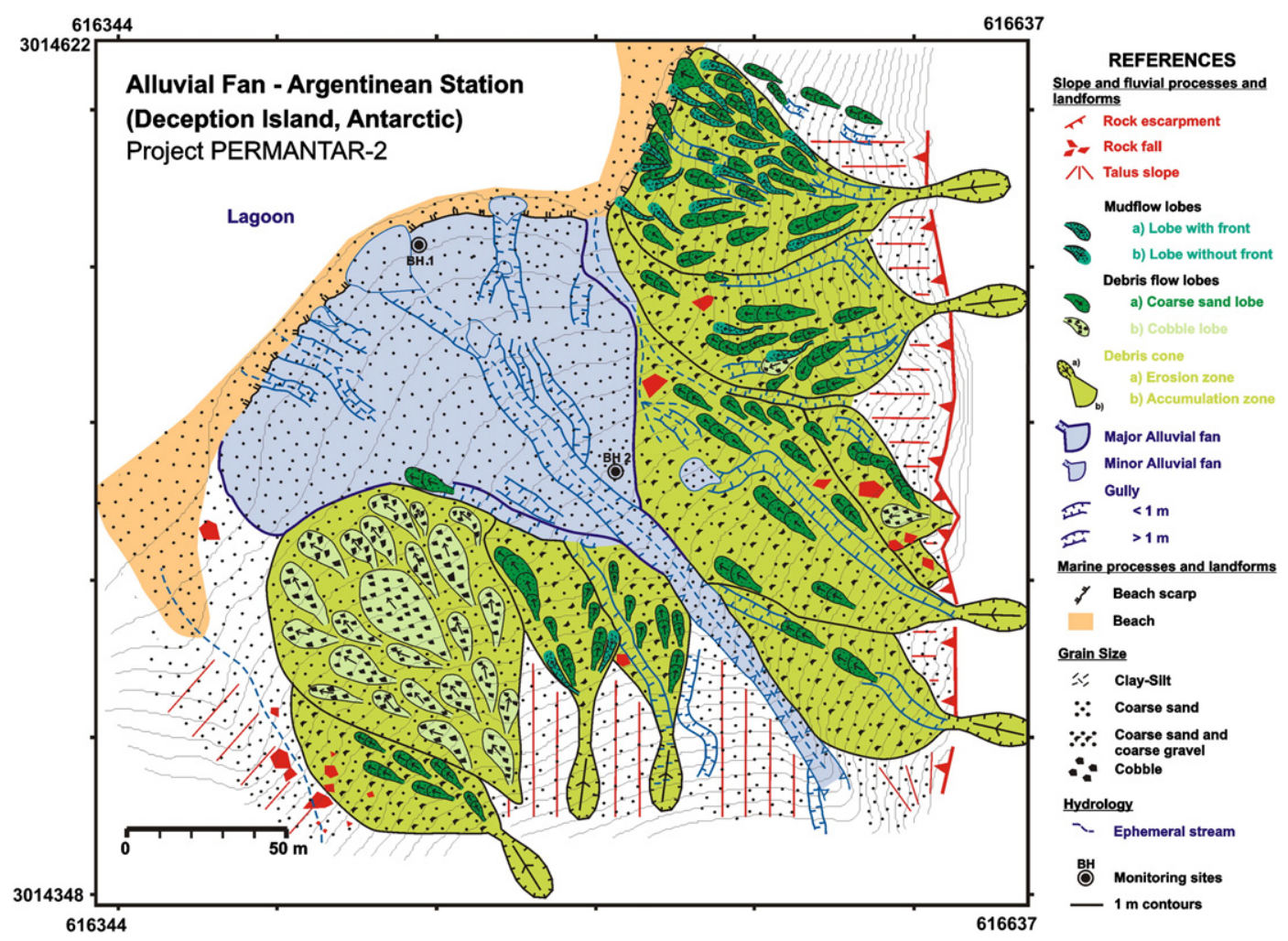

Fig. 2. Geomorphology of the Irizar alluvial fan detailed study area. 
Planchon-Peteroa volcano (Southern Andes, Argentina) over the last 14,000 years. A highlight research is presented by Abramov et al. (2008), where geocryological conditions in Klyuchevskaya volcano group (Kamchatka Peninsula) are described. Besides, they estimated the spatial distribution of permafrost on thermally anomalous terrain using a simple statistical model. Moreover, Beget et al. (2005) described in Arctic Alaska giant explosion craters produced by numerous explosions caused by cryo-magmatic interactions, where the water source for continued explosive volcanism is the melting of ground ice.

This paper focuses on the thermal and geomorphic characterization of one of the areas in Deception Island with permafrost close to a geothermal anomaly sector showing no fumarole activity. Between 2010 and 2012, we conducted fieldwork to investigate ground temperatures at different depths and their spatial patterns, temperature in two boreholes, electrical resistivities, thaw depths and the main landforms of the site were studied and mapped. In order to analyze how meteorological factors affect subsurface temperatures, air and soil temperatures and snow thickness were measured.

\section{Regional setting}

Deception Island $\left(62^{\circ} 57^{\prime} \mathrm{S} ; 60^{\circ} 38^{\prime} \mathrm{W}\right)$ is the south-westernmost island of the Bransfield Strait (Fig. 1). It presents a horseshoe-like shape with an opening in the south-east sector (Neptune Bellows) and a flooded caldera (Port Foster). The volcanic activity on the island developed in the last 0.2 Ma (Keller et al., 1991) and the latest eruptions occurred in 1967, 1969 and 1970, destroying the Chilean research station and severely damaging the British station. Subaerial fumaroles and underwater degassing sites are common in several areas on and offshore at Deception Island (Grad et al., 1992; Acosta and Uchupi, 1996; Smellie and López-Martínez, 2000). A regional tectonic extension is traditionally suggested to explain these sequences of volcanic and hydrothermal events (Rey et al., 1995) and the structural lineament directions inside the island control the eruption's places and the main geomorphological features (Maestro et al., 2007). Besides, these structural patterns also restrict present fumaroles and anomalous ground temperature locations.

Subaerial fumaroles and underwater degassing sites are related to venting from shallow aquifers heated by convective gaseous inflow from an underlying magma chamber (Ramos et al., 1989). Temperatures as high as $107^{\circ} \mathrm{C}$ have been recorded in beach interstitial waters close to the fumarole emissions (Villegas and Caselli, 1995; Caselli et al., 2004). In Port Foster itself, seawater surface temperatures vary between $0{ }^{\circ} \mathrm{C}$ and $-1{ }^{\circ} \mathrm{C}$ close to Neptunes Bellows and exceed $3{ }^{\circ} \mathrm{C}$ in the centre of the bay (Rey et al., 1997), but temperatures between 7 and $15{ }^{\circ} \mathrm{C}$ in surface waters have been measured in small bays around Port Foster (Dykes et al., 2001).

The surface of the island is covered by glaciers and thick sheets of ashes and pyroclastic rocks expelled by recent volcano activity. These deposits are very porous and favour the development of a permafrost with a high ice content (Vieira et al., 2008).

Climate is cold-oceanic at sea level, with frequent summer rainfalls and a moderate annual temperature range. Mean annual air temperatures are close to $-2{ }^{\circ} \mathrm{C}$ at sea level and average relative humidity is very high, ranging from 80 to 90\% (Simonov, 1977; Rakusa-Susczewski, 1993). The ground freezing season in the island extends from autumn to mid-spring, whereas the thawing period is shorter and associated with the austral summer (Ramos et al., 2012).

This study focuses on an ice-free area in the northern slope of Mount Irizar, in the vicinity of the Argentine Antarctic Station Decepción (Fig. 2). It corresponds to an alluvial fan and a few debris cones that enter a lagoon. It is one of the areas with geothermal anomalies in the island, as was evidenced by early reports from 1829 (Clapperton, 1969; Roobol, 1972, 1982); however, no fumarole activity occurs.

\section{Methodology}

\subsection{Geomorphological mapping}

A DGPS (differential GPS) Trimble in continuous RTK (real-time kinematic) mode was used to produce the detailed topographic map in the site. The spacing between data collection points was 2 meters. This map was subsequently used for the detailed geomorphological mapping and for the topographic correction of data acquired in the geophysical survey.

Landforms were mapped at different scales, from a regional perspective through satellite imagery to individual identification recognized in the field. A 1-m resolution QuickBird image from 2003 and a series of aerial photographs ranging from 1957 to 1979 (1:26.000 scale) were used.

\subsection{Spatial distribution of ground temperature and thaw thickness}

In order to assess the spatial variability of ground temperatures, instantaneous measurements have been obtained in January 2011. A hand-held digital thermometer (accuracy of $0.1{ }^{\circ} \mathrm{C}$ ) was used and temperatures were measured at $0.05,0.50$ and $0.70 \mathrm{~m}$ depth. Data were collected in an irregular grid with c. $25 \mathrm{~m}$ intervals and 30 points were considered. In addition at each temperature measuring point, thaw depth was measured with a thin rigid metal rod calibrated in centimetre increments and pushed vertically into the soil to the depth at which ice-bonded soil provides firm resistance. Temperature and thaw depth data were then processed using the Kriging algorithm method because it uses more variables in the weighting of the data and not only the proximity criterion, obtaining thus more accurate estimates (Walvoort and Gruijter, 2001; Hipp et al., 2012; Huo and Zhang, 2012; Janke et al., 2012; Shi, 2014).

\subsection{Air, soil and subsurface temperature and snow depth for continuous monitoring}

Shallow boreholes down to $0.8 \mathrm{~m}$ depth were equipped with sensors for a year-round temperature monitoring. They were installed in January 2011 at the lower (BH1, $2 \mathrm{~m}$ asl) and at the upper area (BH2, $27 \mathrm{~m}$ asl) of the Irizar alluvial fan (Goyanes et al., 2011, 2012). They are located c. $100 \mathrm{~m}$ apart and are installed in sandy gravelly, poorly stratified pyroclasts of alluvio-colluvial origin (Fig. 2). The boreholes were tubed with a plastic pipe cased at the bottom and top in order to prevent water infiltration and air fluxes. The influence of the plastic pipe, with $3 \mathrm{~mm}$ thickness, $0.05 \mathrm{~m}$ width and rising a few centimetres above the soil surface, on the ground thermal regime is negligible (Guglielmin et al., 2012). Ground temperatures were monitored at hourly intervals at $0.05,0.10,0.15,0.20,0.40$ and $0.80 \mathrm{~m}$ depths using Hobo Pendant miniature loggers (www.onsetcomp.com/) with a resolution of $0.3{ }^{\circ} \mathrm{C}$. Temperature data collected were then processed also using Kriging interpolation method. IButton loggers (resolution $\pm 0.5{ }^{\circ} \mathrm{C}$; Maxim, www.maxim-ic.com/products/ibutton/) were installed just below the soil surface, at $0.02 \mathrm{~m}$ depth, close to the boreholes in order to measure ground surface temperature. Each iButton logger was installed in $0.15 \times 0.15 \times 0.04 \mathrm{~m}$ high thermal diffusivity aluminium plates in order to better approach average ground temperatures.

With the aim to analyse the effect of meteorological factors on subsurface temperature at the borehole sites, air temperature Tinytag dataloggers (resolution $\pm 0.1{ }^{\circ} \mathrm{C}$; www.geminidataloggers.com/) were installed $1.5 \mathrm{~m}$ above the ground in a standard meteorological shelter in both borehole sites. The snow depth variation was characterized using temperature sensors (iButtons) at different heights (at 0.025 , $0.05,0.10,0.20,0.40,0.80$ and $1.60 \mathrm{~m}$ ) in a vertical array (Lewkowicz, 2008). Air temperatures were also monitored at each site at three hour intervals. Closer sensor spacing near the ground allows for more 
precise measurements for thinner snow packs. Larger spacing at height was used due to funding constraints and also because the snow pack is not that thick in the area. The principle of this technique is that sensors located beneath the snow surface experience different temperatures and diurnal temperature ranges than those exposed to the air. The snow surface level is inferred by comparing the temperature measured at different heights with air temperatures and by applying the algorithm proposed by Lewkowicz (2008).

In this paper, we analyse borehole, air and snowpack data recorded between 4 February 2011 and the 21 January 2012.

\subsection{Electrical resistivity surveying}

Because a marked increase in electrical resistivity occurs at the freezing point, electrical methods are most suitable to detect, localize and characterize structures containing frozen material (Hauck et al., 2007). Geophysical techniques show very low environmental impact and are therefore very valuable for application in a sensitive and protected environment like the Antarctic Specially Managed Area of Deception Island (ASMA nr 4).

We have conducted electrical resistivity tomography (ERT) for detecting the spatial variability of frozen terrain in the Irizar alluvial fan. The survey was conducted during January 2011. Temperatures in the shallow boreholes and mechanical probing were used for cross validating the resulting data sets.

Nine ERT profiles were conducted using a Lippmann 4-point light 10 W resistivity meter with up to 16 electrodes and minimum electrode spacing between $2.5 \mathrm{~m}$ and $5 \mathrm{~m}$, depending on the desired investigation depth. The resistivity meter was connected to various 4-electrode combinations (quadrupoles) in a Wenner configuration to yield an apparent resistivity data set suitable for tomographic inversion. The observed apparent resistivities were then inverted using the tomographic inversion scheme Res2DINV (Loke and Barker, 1995). Inversion parameters were chosen according to Hauck and Vonder Mühll (2003) to obtain reliable results in cases of strong resistivity contrasts.

\section{Results}

\subsection{Geomorphic dynamics}

The landscape of Deception Island is dominated by the effects of the last volcanic eruptions that have occurred along its inner rim, with the formation of cinder cones and crater-lakes from maar and phreatomagmatic events (Torrecillas et al., 2012). Current geomorphological dynamics is dominated by water erosion associated with snow and glacier melt, which actively transport sediments from the recent volcanic deposits. Active layer thaw associated to the high water content of the surficial soils generates very active geomorphological dynamics dominated by debris flows, mud flows and solifluction, while frost weathering is also a very active process. The volcanic surfaces are also easily affected by wind erosion, with widespread lagsurfaces in many areas.

In the studied zone, the debris cones show slopes $>15^{\circ}$ generated from debris flow and mudflow activity (Fig. 2). The main sediment sources are gullies in the rock escarpments. The free faces of the scarps are eastward oriented, have c. $10 \mathrm{~m}$ height and are associated to consolidate pyroclastic strata. Talus slopes occur at the base of the scarp and are affected by frequent rock fall episodes with blocks exceeding $4 \mathrm{~m}$.

The largest alluvial fan shows a slope of $3-10^{\circ}$ and is dominated by run-off processes. The ephemeral-short-lived fluvial streams are active during snow melt and active layer thaw in late spring and early summer or during rainfall events. Gullies are c. 2 m deep near the escarpment and a few decimetres towards the lower part of the fan. A beach of volcanic gravels with a c. $0.2 \mathrm{~m}$ high beach scarp occurs in the lagoon margin.

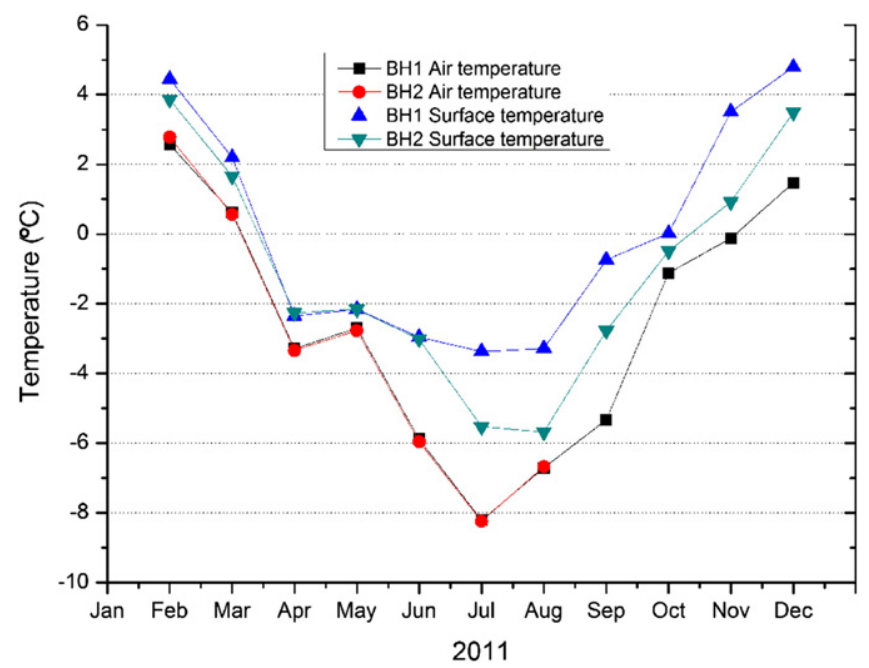

Fig. 3. Monthly air and ground surface temperatures for 2011 at BH1 and BH2 in the Irizar alluvial fan.

The sediments of the fan surface are coarse sands and gravels not exceeding $0.03 \mathrm{~m}$ and their sources are nut-brown pyroclastic surge beds that emerge in the area. A special case is the debris cone located in the southwest part of the study site. It shows debris flow deposits with gravels larger $0.05 \mathrm{~m}$, reflecting a source area both in the yellow pyroclastic flows and the surge deposits occurring at the north slope of Mount Irizar, outside of the studied site.

\subsection{Ground temperature regimes}

Mean monthly air temperatures recorded at both sites in the Irizar alluvial fan were similar since there is only $100 \mathrm{~m}$ distance between the two shallow boreholes. Since in early September the BH2 air temperature datalogger failed, we only refer to $\mathrm{BH} 1$ air temperature, which is comparable (Fig. 3). The mean monthly air temperature ranged from $2.6{ }^{\circ} \mathrm{C}$ to $-8.5{ }^{\circ} \mathrm{C}$ and the mean annual air temperature was $-2.6{ }^{\circ} \mathrm{C}$. From April to September daily air temperatures remained generally below $0{ }^{\circ} \mathrm{C}$ and from October to January temperatures were generally slightly above $0{ }^{\circ} \mathrm{C}$.

Mean annual ground surface temperatures were slightly warmer at $\mathrm{BH} 1\left(0{ }^{\circ} \mathrm{C}\right)$ than at $\mathrm{BH} 2\left(-1{ }^{\circ} \mathrm{C}\right)$ (Fig. 3$)$. Mean monthly values were also similar except from July to September, where at BH1 the temperatures remained close to $-3{ }^{\circ} \mathrm{C}$, while at $\mathrm{BH} 2$ the mean monthly temperatures reached $-6{ }^{\circ} \mathrm{C}$. Mean monthly ground surface temperature in both areas was always warmer than air temperature. An episode of air and ground surface temperature increase known as "coreless winter" (Van Loon, 1967; Guglielmin and Dramis, 1999; Guglielmin and Cannone, 2012) was observed. It shows a temperature increase up to $1{ }^{\circ} \mathrm{C}$ from one month to another, and occurred in May 2011. The occurrence of coreless winters in the South Shetland Islands region is mainly attributed to: (1) increase in the intensity of cyclonic circulation and to the presence of massive and rapid advection of warm air northerly and westerly (Van Loon, 1967; King and Turner, 1997); and (2) a large-scale oceanic processes like the presence of positive anomalies in sea surface temperature and the retreat of sea ice extent southwards (Styszynska, 2004).

Snow depth ranged from 0 to $0.10 \mathrm{~m}$ with a rather irregular thickness and reaching maximum thickness during September. Winter snow cover started not before August favouring a good coupling between air and ground temperature during the core of the winter. 
a
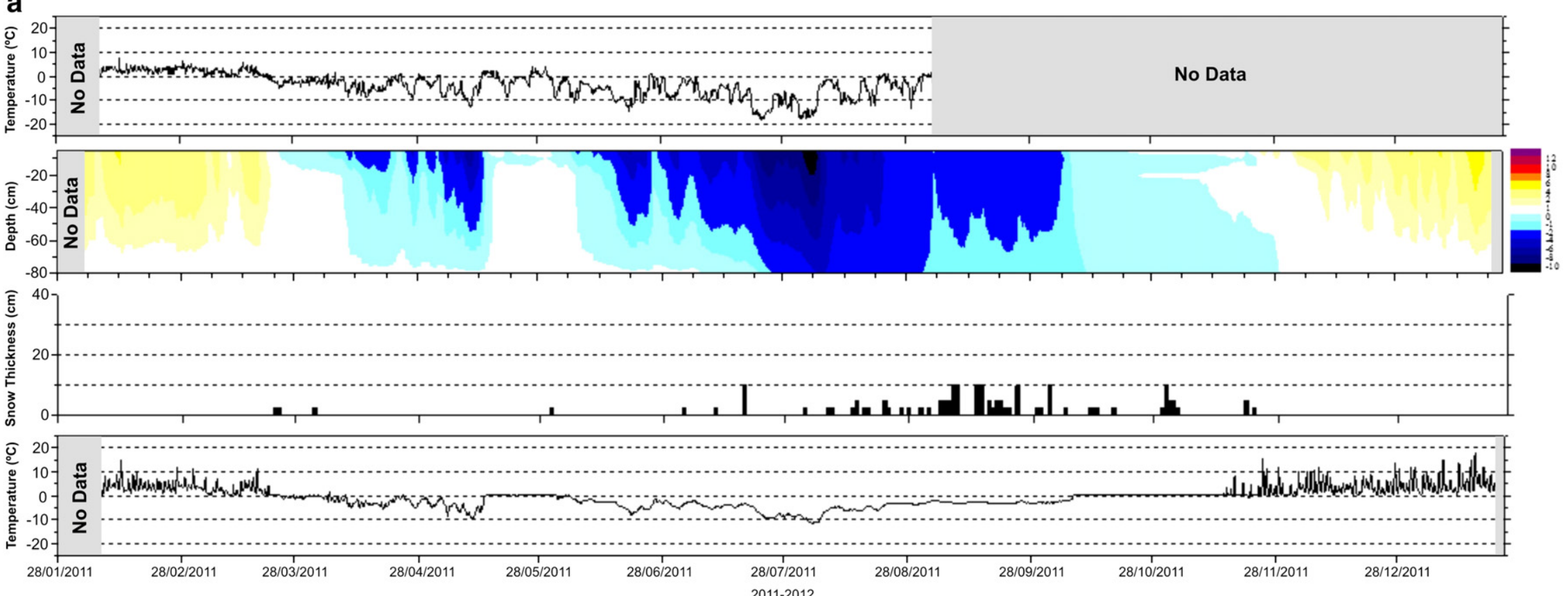

b
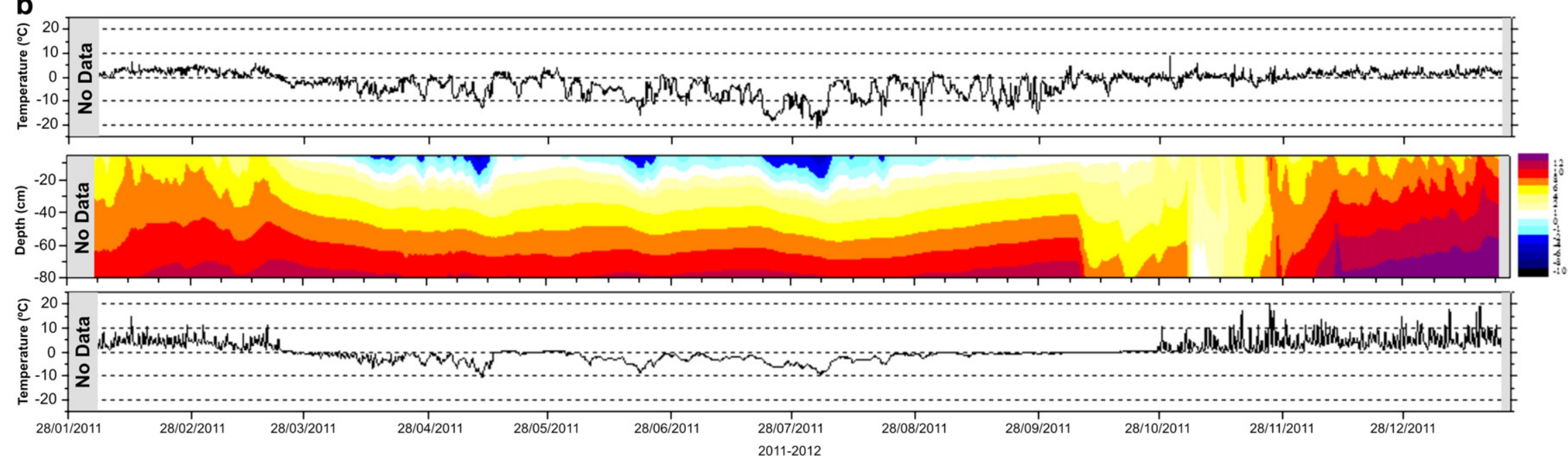

Fig. 4. Daily regime for air, surface and ground temperatures and snow depth at BH2 (a) and BH1 (b) boreholes in the Irizar alluvial fan during 2011. 

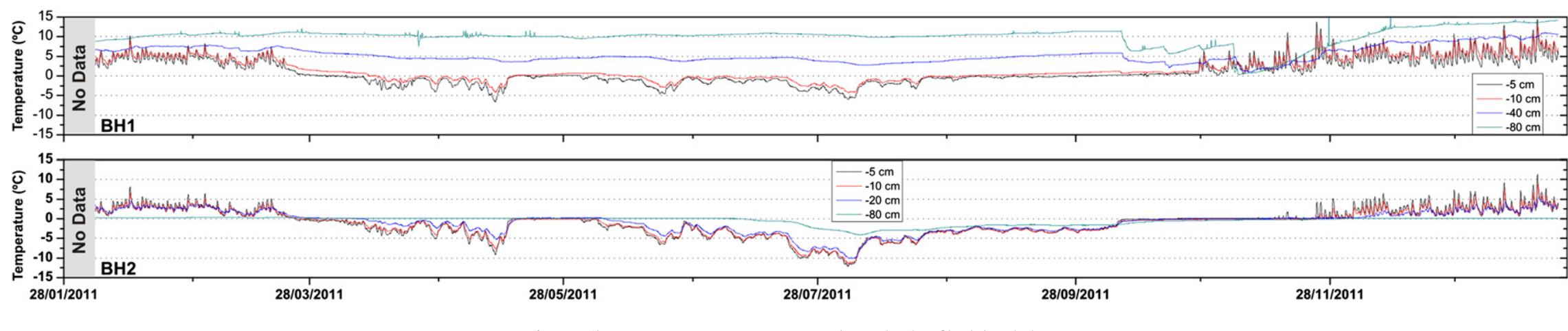
The scarce snow cover allowed for a fast cooling of the ground in site BH2 (Fig. 4).

Ground temperature regimes of the two boreholes were very different, despite the proximity between both sites (Figs. 4 and 5). The thaw season took place in February and March 2011 and from October 2011 to January 2012, while the freezing season took place from April to September 2011. The bottom of BH2 $(0.7-0.8 \mathrm{~m})$ was frozen all year-round and during the core of the winter it cooled to $-4{ }^{\circ} \mathrm{C}$. The ground surface showed temperatures below $-6{ }^{\circ} \mathrm{C}$ during the winter, lowering below $-10{ }^{\circ} \mathrm{C}$ for some days. During the summer, surface temperatures were close to $3{ }^{\circ} \mathrm{C}$, having reached nearly $5{ }^{\circ} \mathrm{C}$ in January 2012.

Two warming events took place during the 2011 cold season, one from mid-May to mid-June and from early September to early October at BH2. The first case is due to the air temperature increase together with the absence of a snow cover which allows good energy exchange between atmosphere and ground. Here, the whole active layer warmed to $0{ }^{\circ} \mathrm{C}$. The second case seems to be related with the beginning of the thaw season, although the snow cover prevented the fast warming effect of the air temperature.

BH1 showed a stable thermal regime all year-round and changes in air temperature only influenced a shallow layer down to $0.20 \mathrm{~m}$ depth. During the thaw season there was a warming at all depths, reaching temperatures above $13{ }^{\circ} \mathrm{C}$ at $0.8 \mathrm{~m}$ and $6{ }^{\circ} \mathrm{C}$ near the surface. During the freezing period, ground at $0.80 \mathrm{~m}$ cooled to $11^{\circ} \mathrm{C}$ and the thermal stratification was clearer, with temperatures of $-4{ }^{\circ} \mathrm{C}$ near the surface. A remarkable feature is that temperature quickly declined at all depths in early October (c. $6{ }^{\circ} \mathrm{C}$ ), a situation that lasted to the
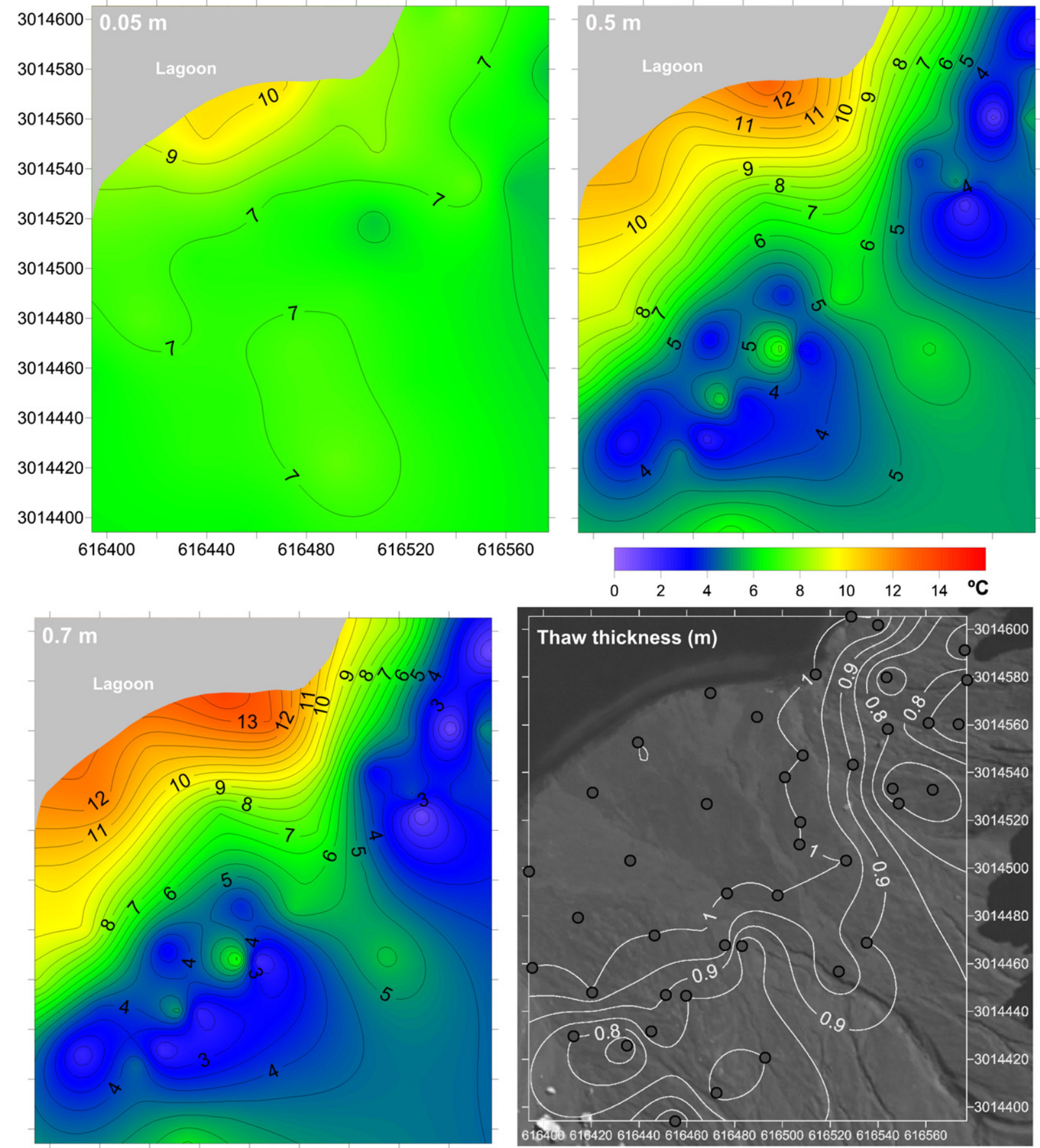

Fig. 6. Instantaneous diurnal ground temperatures at $0.05,0.50$ and $0.7 \mathrm{~m}$ depth, and thaw depths in the Irizar alluvial fan. Dots represent the probing sites. 

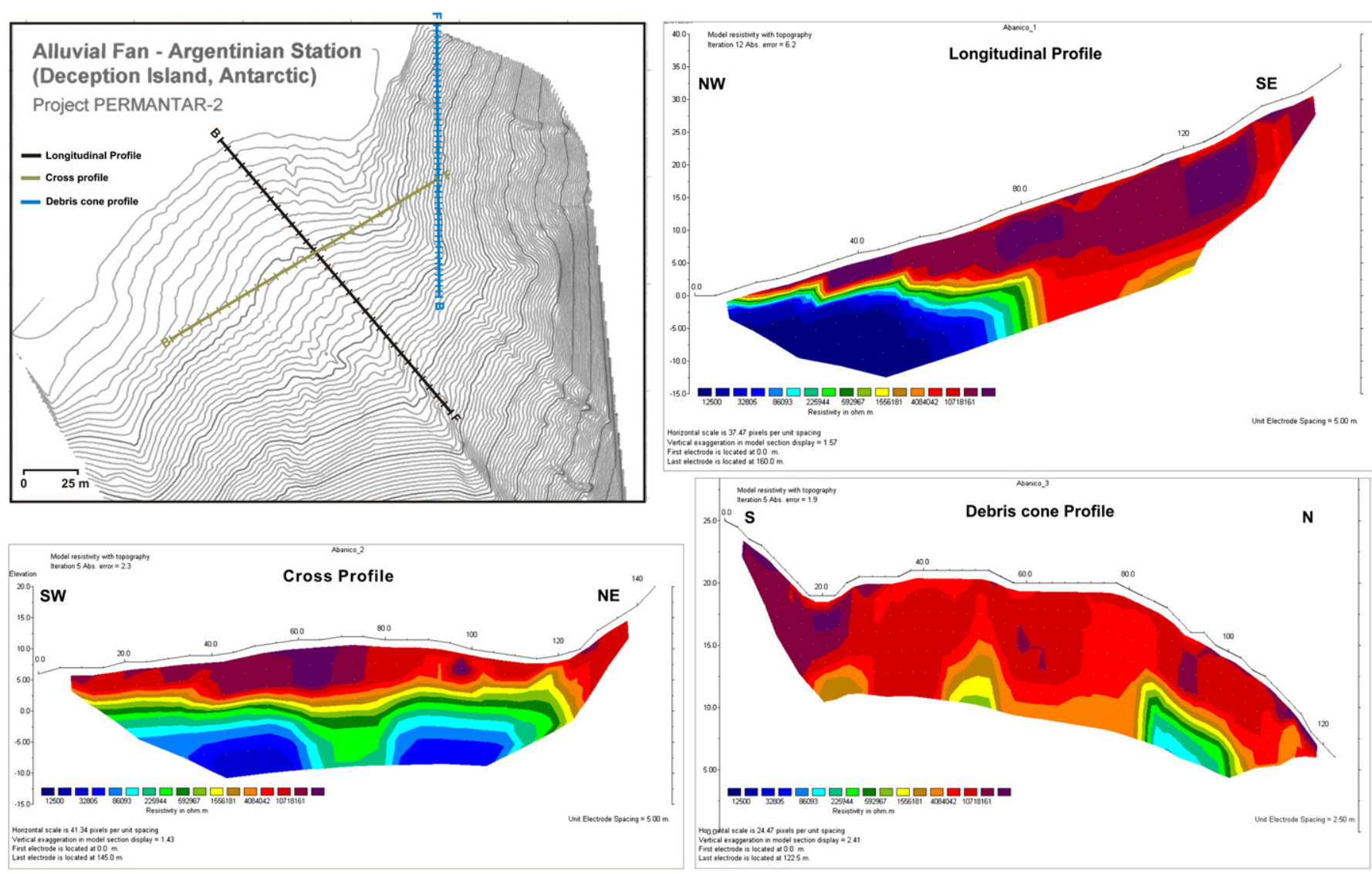

Fig. 7. Electrical resistivity tomographies in the Irizar alluvial fan and debris cones. Two distinct areas are visible: a more conductive deeper zone and a highly resistive shallow zone.

beginning of December. This feature probably is due to the penetration of cold water at depth from the melt of both the snow pack and the seasonal frozen layer.

\subsection{Spatial variability of summer ground temperatures and thaw depth}

Instantaneous ground temperature data from 5 February 2011 show a clear spatial pattern with highest temperatures found near the lagoon and the lowest values located in the debris cones area (Fig. 6). Spatial temperature distributions at 0.5 and $0.7 \mathrm{~m}$ depth show a similar general pattern, reaching values greater than $13{ }^{\circ} \mathrm{C}$ in the coast and values near to $0{ }^{\circ} \mathrm{C}$ in remote areas to it. At these depths, there is a narrow transition zone between the highest and lowest temperature sectors near the debris cones and in the middle of the alluvial fan. There are two contrasting situations: (1) along the main ephemeral channel of the alluvial fan (NW-SE direction), where the temperature $\left(\right.$ c. $5-7.5{ }^{\circ} \mathrm{C}$ ) is higher than the surrounding areas, (2) at the core of the debris cones, where lower temperatures $\left(1-3{ }^{\circ} \mathrm{C}\right)$ were found at depth.

Spatial distribution of thaw depth indicates that frozen ground is absent or below $1.1 \mathrm{~m}$ (maximum limit of probe length) in the northwestern part of study site, close to the lagoon. The southeastern sector, on the slope and further away from the lagoon, consistently shows shallower thaw depths, reaching $0.7 \mathrm{~m}$ depth (Fig. 6). Similarly to the ground temperature survey, along the main ephemeral channel of the alluvial fan the thaw thickness is larger than in the surrounding areas. In the debris cones the thaw depth is thinnest.

Lagoon water temperatures were measured on 5 February 2011 near the alluvial fan and $150 \mathrm{~m}$ away (near the old Argentinean meteorological station), reaching values of $8.3^{\circ} \mathrm{C}$ and $5.6{ }^{\circ} \mathrm{C}$ respectively.

\subsection{Electrical resistivity surveys}

Fig. 7 shows the ERT results for the alluvial fan and debris cones. They show two distinct zones: (1) the alluvial fan next to the lagoon, where specific electrical resistivity values at depth range from 12 to $32 \mathrm{k}-\mathrm{ohm}-\mathrm{m}$; and (2) the upper sector of the alluvial fan and debris cones, and on the surface layer near the lagoon where resistivity values range from 1.5 to $10 \mathrm{M}$-ohm- $\mathrm{m}$. These values are considerably higher than the range of resistivity values found in previous electrical resistivity surveys on Deception and Livingston Island (Hauck et al., 2007) and also than in the European Alps (Hauck and Vonder Mühll, 2003). Such high values may be due to that some electrodes were located in very dry ash. Laboratory experiments showed that dry ash has a very high resistivity $\left(\rho>1.56 \times 10^{7} \Omega \mathrm{m}\right)$ due to the crystallo-solid structure of the salts (Wardman et al., 2012).

The longitudinal ERT profile along the alluvial fan shows that the higher resistivity zone has a wedge shape towards the coast, where values decrease fast. The cross section also detects the lower boundary of the zone of higher resistivity values close to lagoon water level. Because of the comparative large electrode spacing $(5 \mathrm{~m})$ the thaw thickness is not detectable in the tomographies.

The debris cone section evidences a shallow resistive zone, with the highest values found to the south, on the upper alluvial fan. On the contrary towards the north, there is a zone with medium resistivity values at depth located at the base of a debris cone near to the lagoon. Here, the lower boundary of high resistivity values is not visible, perhaps because the electrode spacing $(2.5 \mathrm{~m})$ is less than for the other profiles.

ERT data also suggest that permafrost thickness is c. 5-7 $\mathrm{m}$ in the mid to upper parts of the fan. 

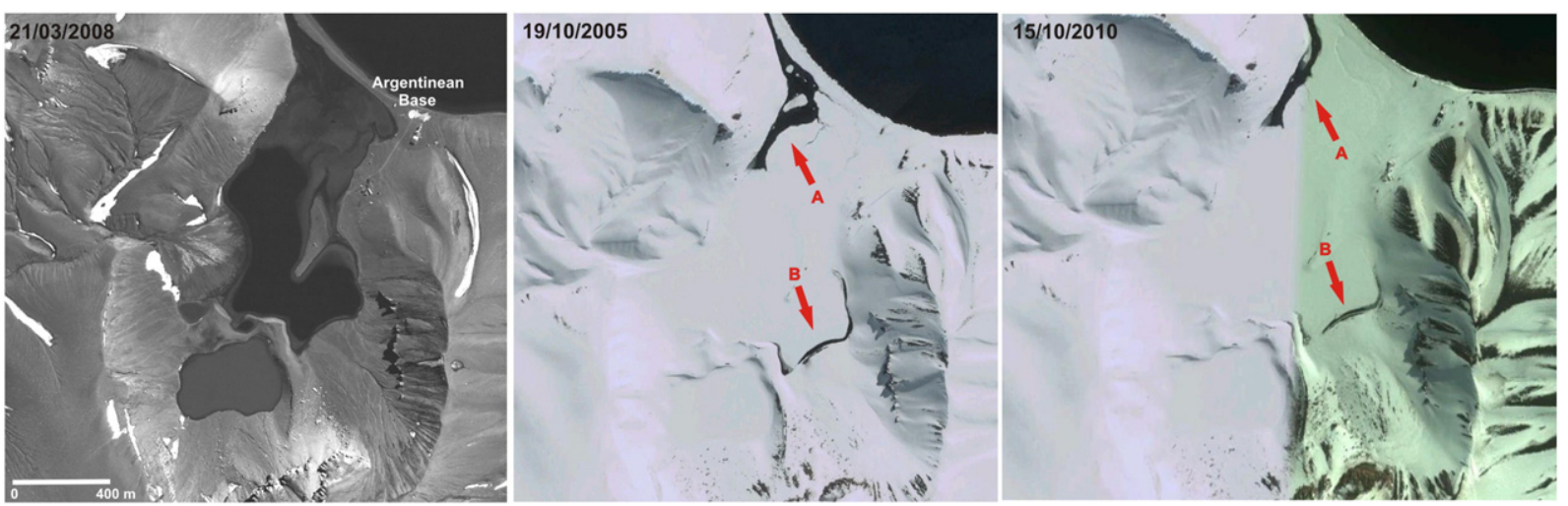

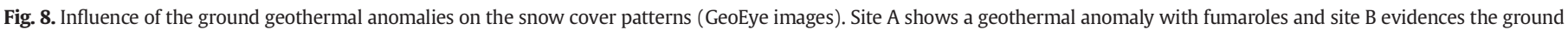
geothermal anomalous site studied in this work.

\section{Discussion}

The temperature regime, ERT surveys, instantaneous summer temperature patterns and thaw depths, indicate the occurrence of permafrost at c. $0.7 \mathrm{~m}$ depth at borehole BH2. During the year, borehole temperatures showed a good correlation with air temperatures because of the thin snow cover and high cloudiness (Ishikawa, 2003; Oht, 2003; Guglielmin, 2004). Only in September-October 2011, when a permanent and continuous snow cover formed, ground temperatures become decoupled from air forcing.

Since permafrost is widespread in all Deception Island, down to beach level (Ramos et al., 1989, 2012; Vieira et al., 2010), the temperature data obtained from $\mathrm{BH} 1$, from the instantaneous survey with the hand thermometer and the shallow water temperatures measured at the base of the alluvial fan show the influence of a geothermal anomaly. This anomalous warm behaviour in the site should be the result of the volcanic-hydrothermal processes occurring at depth (Rey et al., 1995; Martí et al., 1996). Thus, they inhibit permafrost development in the coastal fringe, as well as ground frost below $0.20 \mathrm{~m}$, even when the air temperature falls below $0{ }^{\circ} \mathrm{C}$. The lagoon water temperature measured near the old meteorological station, the thermal regime of $\mathrm{BH} 2$ and the lowest temperature values obtained with the hand thermometer, suggest that the effects of the geothermal anomaly are restricted to a very narrow fringe.

The more conductive zone of the ERT may be evidencing the effect of a salty lagoon water wedge into the alluvial fan (Urish and Frohlich, 1990). The resistivity of the water depends on the concentration and type of dissolved minerals and salts (Lowrie, 2007, pp. 252-276). Sea water has low resistivity values because of the high conductivity of the ions to the dissolved salt (Telford, 1990, pp. 565-568; Reynolds, 1997, pp. 417-490). On the other hand, resistivity values for frozen ground can vary over a wide range, from between 1 and $5 \mathrm{k} \Omega \mathrm{m}$, to several hundred $\mathrm{k} \Omega \mathrm{m}$ or even a few $\mathrm{M} \Omega \mathrm{m}$ (Kneisel and Hauck, 2008, pp. $3-27)$. The high resistivities found some tens of meters from the coastline, together with temperature and probing data relate to the presence of permafrost, seemingly 5-7 $\mathrm{m}$ thick. The very high resistivities probably reflect a high ice content (Kneisel and Hauck, 2008, pp.3-27), but the complex-variable chemical composition of the ground typical of anomalous geothermal settings (Caselli et al., 2004, 2007) may also be affecting resistivity values.

The local effect of the geothermal anomaly on controlling permafrost distribution seems to be present throughout the year as is suggested by the GeoEye satellite imagery. These show discontinuous snow cover at the lower part of the alluvial fan during the spring months in scenes

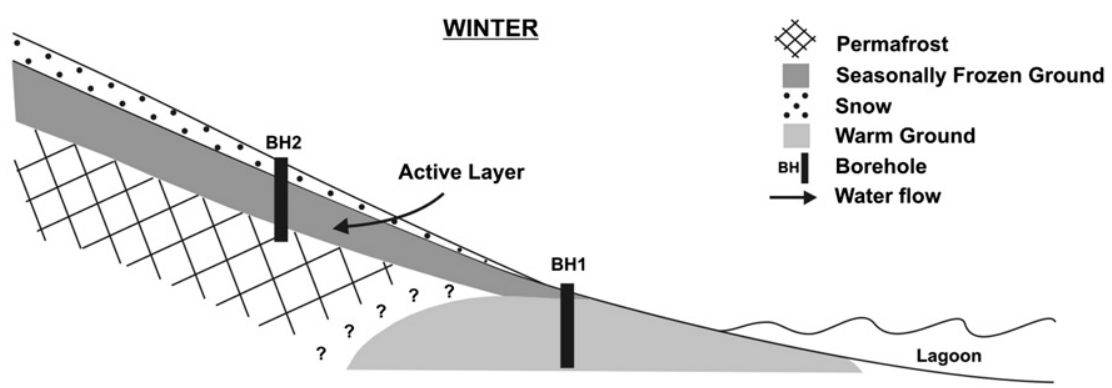

OCTOBER

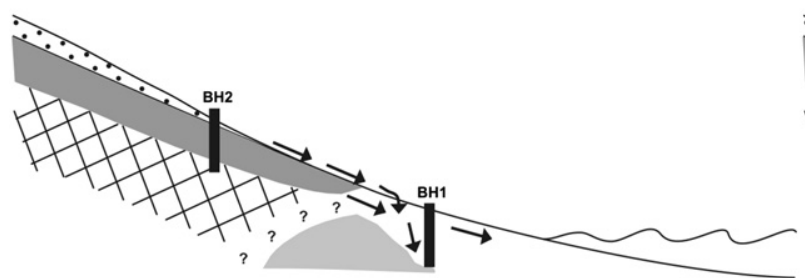

NOVEMBER

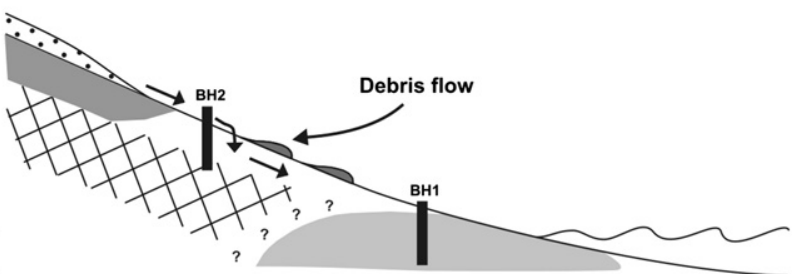

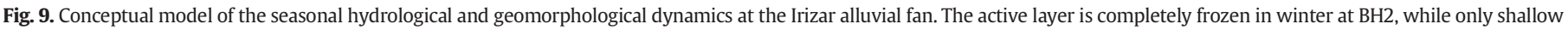

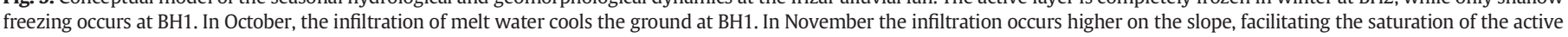
layer and contributing to debris flow processes, while thermal stratification returns to $\mathrm{BH}$. 


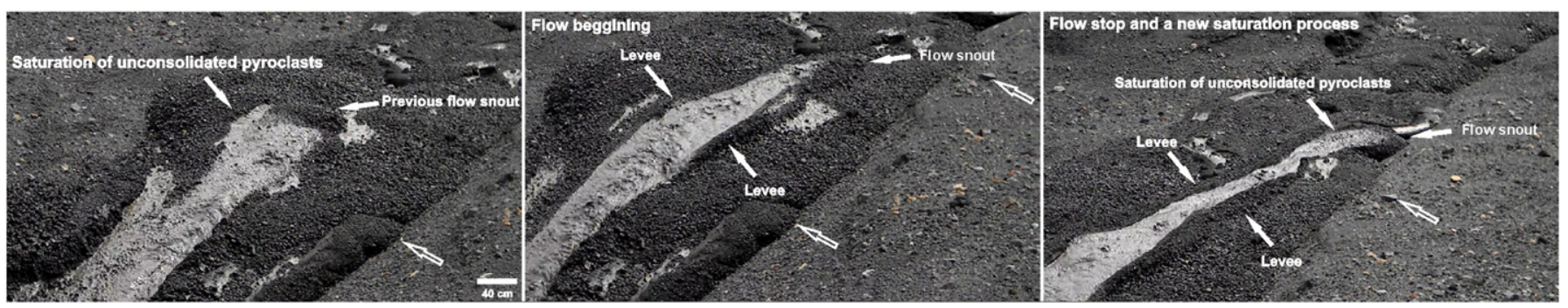

Fig. 10. Stages of debris flow origin at the alluvial fan site.

from 2005 and 2010 (Fig. 8). Historical documentation from other expeditions refers to this pattern at least since 1829 (Roobol, 1972, 1982).

The fast decline in temperature at BH1 in early October 2011 deserves special mention. It matches the beginning of the snow melt period as is evidenced by air temperature values above $0{ }^{\circ} \mathrm{C}$. Snow melt water from upslope (there is no snow at $\mathrm{BH} 1$ ) percolates into the warm soil and moves into the site, causing the temperature to fall. Such an event shows different reaction in BH2. There, the snow starts melting approximately at the same date, but shows a small and slow warming (opposite) effect on ground temperatures. This is related to the freezing curtain associated to latent heat absorption during thaw, allowing temperatures to remain stable until late November, when ground starts to thaw.

The comparison between the timing and style of events in $\mathrm{BH} 1$ and $\mathrm{BH} 2$, which are placed along a topographical transect, provides important hints about the hydrological influence of the geothermal anomalies. The cooling event in BH1 lasts from early October to late November and is characterized by two pulses. The first pulse finished in early November and represents an episode of water availability from the upslope melting of the snow pack and the active layer. In the end of November, ground temperatures start to increase progressively and in two weeks they become warmer than during the previous winter-spring. The beginning of warming coincides with the progression of thaw in $\mathrm{BH} 2$, c. $100 \mathrm{~m}$ upslope. This indicates that water that was percolating from upslope ceased to reach to BH1, allowing it to warm. Such behaviour should be linked to the continuous thawing along a seasonal frost wedge developing between $\mathrm{BH} 1$ and $\mathrm{BH} 2$, which progressively allowed water to infiltrate more upslope (Fig. 9).

The upslope retrogression in the infiltration of melt water accompanying snow melting and thawing of seasonal frost, together with the increase of the slope gradient in the debris cones head gives rise to the instability of the slopes generating debris flow processes. These are initiated by the saturation of surface unconsolidated material due to the presence of an impermeable frozen layer at depth followed by flow along a channel in the slope, reworking the slope material (Vieira et al., 2008). Rainfall and snowfall episodes during the summer season also can be the trigger mechanism for the debris flows as has been observed in the area (Goyanes et al., 2011). Fig. 10 shows details of such slow moving debris flows. The first image shows a water and sediment accumulation behind the head of a previous flow deposit. Here, the water percolates in the very porous pyroclasts saturating rapidly the surficial bed due to the frozen ground occurrence at depth. Then, when it overcomes the resistance of the material, the debris flows movement begins. Downslope, when the debris flow stops due to the loss of water and by a friction increase, a new episode of water and sediment accumulation behind the debris flow lobe occurs.

The results also evidence the effect of micro-topography on active layer depth (Cannone et al., 2008). Greater active layer depth and higher temperatures at the ephemeral stream of the alluvial fan were probably the result of heat transfer from water flow that was observed to percolate through the subsurface from the adjacent hillside and also from the central part of the debris cones, which are topographically elevated sites
(Adlam et al., 2010). This process probably accelerated the thawing action along the channels and lowland sites.

The observations indicate an intricate pattern of thawing of the active layer and consequent water percolation over the warming frost table, leading to the concentration of flow along the main channels of the alluvial fan. The geomorphic implications of these are not clear yet, but may indicate that alluvial fans with permafrost can be prone to a different erosion regime than those with seasonally frozen ground. In sites with permafrost occurrence, water cannot infiltrate, therefore flows above the permafrost table, causing gully erosion. On the contrary, where frozen ground is absent, water percolates in the highly porous pyroclastic material inhibiting the surficial erosion.

\section{Conclusions}

Geothermal anomalies in Deception Island are frequent but their role on permafrost distribution had not yet been studied. The observations made with thermometry, thaw depth probing and electrical resistivity tomography in the Irizar alluvial fan show the presence of anomalous warm ground in the lower part of the fan, with temperature at shallow depth of c. $13{ }^{\circ} \mathrm{C}$ all year-round. This may be due to volcanichydrothermal processes at depth. High temperatures inhibit permafrost development in a narrow fringe (c. $100 \mathrm{~m}$ ) close to the coast line. Probably this restricted control on permafrost distribution is favoured by the high ice content of the frozen ground together with a very local heat source.

The comparison between the timing and style of events in a shallow borehole located in the anomalous temperature area and another located outside it, evidenced the local influence of the geothermal anomaly on the active layer hydrology of the site. In the former site, the ground remains mostly unfrozen, with only short and surficial freezing events during the cold season, while in the later, located c. $100 \mathrm{~m}$ upslope, the ground freezes down to $0.80 \mathrm{~m}$ and the data indicate that permafrost is present underneath. The presence of such an impermeable frozen layer in the upper parts of the fan and debris cones favours the generation of debris flow processes due to the saturation of the active layer during warm spring and summer events. The sharp horizontal gradient between frozen and unfrozen ground due to the anomalous heat flux generates a zonation in the water infiltration in the fan and possibly on the action of chemical weathering and precipitation, which are favoured towards the lower part of the fan. The later hypothesis should be further studied in forthcoming campaigns.

\section{Acknowledgements}

This study was conducted as part of the projects PERMANTAR-2 (Permafrost and Climate Change in the Maritime Antarctic - FCT PTDC/AAC-CLI/098885/2008) and "Estudio y seguimiento de volcanes activos: Isla Decepción, Antártida" (PICT-O 36051 and PICT-A 2012-2015).

We thank the "Gabriel de Castilla" Spanish Antarctic Base and "Decepción" Argentinean Antarctic Base for the logistic support on the 
field and the Spanish Antarctic Program for supporting transportation of equipment. We thank the DNA-IAA (Dirección Nacional del Antártico-Instituto Antártico Argentino) and ProPolar (Programa Polar Português - FCT) for funding this joint research program.

Besides, we thank the two anonymous referees for their comments that significantly contributed to improve the manuscript.

\section{References}

Abramov, A., Gruber, S., Gilichinsky, D., 2008. Mountain permafrost on active volcanoes: field data and statistical mapping, Klyuchevskaya Volcano Group, Kamchatka, Russia. Permafr. Periglac. Process. 19, 261-277.

Acosta, J., Uchupi, E., 1996. Transtensional tectonics along the south Scotia Ridge, Antarctica. Tectonophysics 267, 31-56.

Adlam, L.S., Balks, M.R., Seybold, C.A., Campbell, D.I., 2010. Temporal and spatial variation in active layer depth in the McMurdo Sound Region, Antarctica. Antarct. Sci. 22, $45-52$

Beget, J., Kargel, J., Wessels, R., 2005. Landforms produced by permafrost-volcano interactions, Arctic Alaska. Am. Geophys. Union http://adsabs.harvard.edu/abs/2005AGUFM.V12B.07B (Fall Meeting 2005, abstract \#V12B-07)

Bleick, H.A., Coombs, M.L., Cervelli, P.F., Bull, K.F., Wessels, R.L., 2013. Volcano-ice interactions precursory to the 2009 eruption of Redoubt Volcano, Alaska. J. Volcanol. Geotherm. Res. 259, 373-388.

Bockheim, J.G., Campbell, I.B., McLeod, M., 2007. Permafrost distribution and active-laye depths in the McMurdo Dry Valleys, Antarctica. Permafr. Periglac. Process. 18, 217-227.

Bockheim, J., Vieira, G., Ramos, M., López-Martínez, J., Serrano, E., Guglielmin, M. Wilhelm, K., Nieuwendam, A., 2013. Climate warming and permafrost dynamics in the Antarctic Peninsula region. Glob. Planet. Chang. 100, 215-223.

Cannone, N., Wagner, D., Hubberten, H.W., Guglielmin, M., 2008. Biotic and abiotic factors influencing soil properties across a latitudinal gradient in Victoria Land, Antarctica. Geoderma 144, 50-65.

Caselli, A.T., dos Santos Afonso, M., Agusto, M.R., 2004. Gases Fumarólicos de Isla Decepción (Shetland Del Sur, Antártida): Variaciones químicas y depósitos vinculados a la crisis sísmica de 1999. Rev. Asoc Geol. Argent 59, 291-302.

Caselli, A., Badi, G., Bonatto, A.L., Bengoa, C.L., Agusto, M.R., Bidone, A., Ibáñez, J., 2007. Actividad sísmica y composición química fumarólica anómala debido a posible efecto sello en el sistema volcánico, Isla Decepción (Antártida). Rev. Asoc. Geol. Argent. 62, 545-552.

Clapperton, Ch., 1969. The volcanic eruption at Deception Island, December 1967. Brit. Antarct. Surv. Bull. 22, 83-90.

De Rosa, R., Mazzuoli, R., Omarini, R.H., Ventura, G., Viramonte, J.G., 1995. A volcanological model for the historical eruptions at Deception Island (Bransfield Strait, Antarctica). Terra Antarct. 2, 95-101.

Dykes, K., Sturz, A., Gray, S.C., 2001. Investigation of hydrothermal activity at Deception Island, Antarctica. GSA Annual Meeting, Boston, Abstract 26270.

Edwards, B.R., Skilling, I.P., Tuffen, H., Wilson, L., 2009. Volcano-ice interactions on Earth and Mars: the state of the science. J. Volcanol. Geotherm. Res. 185, 247-392.

Goyanes, G., Vieira, G., Caselli, A., Bernardo, I., Santos, F., 2011. Dinámica geomorfológica actual en un área con anomalías geotérmicas y permafrost (Cerro de la Cruz Isla Decepción, Antártida). In: Valcarcel, M., Carrera Gómez, P. (Eds.), III Congreso Ibérico de la International Permafrost Association: Criosferas. Suelos Congelados y Cambio Climático. Universidad de Santiago de Compostela, Piornedo, pp. 83-86.

Goyanes, G., Vieira, G., Caselli, A., Cardoso, M., Marmy, A., Bernardo, I., Hauck, C., 2012. Permafrost-volcano interactions: a case-study in Deception Island. XXXII SCAR, Open Science Conference and XXIV COMNAP AGM, Session 19: Antarctic Permafrost. Periglacial and Ice-Free Environments, Portland (http://scar2012.geol.pdx.edu/doc/ abstracts/Session_19.pdf).

Gràcia, E., Canals, M., Farrán, M., Prieto, M.J., Sorribas, J., Acosta, J., Baraza, J., Bart, P. Calafat, A.M., Casamor, J.L., De Batist, M., Ercilla, G., Francés, G., Ramos, E., Sanz, J.L., Tassone, A., 1996. Morphostructure and evolution of the Central and Eastern Bransfield Basins (NW Antarctic Peninsula). Mar. Geophys. Res. 18, 429-448.

Grad, M., Guterch, A., Sproda, P., 1992. Upper crustal structure of Deception Island, Bransfield Strait, West Antarctica. Antarct. Sci. 4, 469-476.

Guglielmin, M., 2004. Observations on permafrost ground thermal regimes from Antarctica and the Italian Alps, and their relevance to global climate change. Glob. Planet. Chang. 40, 159-167.

Guglielmin, M., Cannone, N., 2012. A permafrost warming in a cooling Antarctica? Clim. Chang. 111, 177-195.

Guglielmin, M., Dramis, F., 1999. Permafrost as a climatic indicator in northern Victoria Land, Antarctica. Ann. Glaciol. 29, 131-135.

Guglielmin, M., Worland, M.R., Cannone, N., 2012. Spatial and temporal variability of ground surface temperature and active layer thickness at the margin of maritime Antarctica, Signy Island. Geomorphology 155-156, 20-33.

Hall, K., 2002. Review of present and quaternary periglacial processes and landforms of the maritime and sub-Antarctic region. S. Afr. J. Sci. 98, 71-81.

Hauck, C., Vonder Mühll, D., 2003. Inversion and interpretation of 2-dimensional geoelectrical measurements for detecting permafrost in mountainous regions. Permafrost Periglac. Process. 14, 305-318.

Hauck, C., Vieira, G., Gruber, S., Blanco, J., Ramos, M., 2007. Geophysical identification of permafrost in Livingston Island, maritime Antarctica. J. Geophys. Res. 112, F02S19. http://dx.doi.org/10.1029/2006JF000544.

Hipp, T., Etzelmüller, B., Farbrot, H., Schuler, T.V., Westermann, S., 2012. Modelling borehole temperatures in Southern Norway-insights into permafrost dynamics during the 20th and 21st century. Cryosphere 6, 553-571.

Huo, J., Zhang, Y., 2012. Long-term monitoring and visualization analysis system for permafrost change on Qinghai-Tibet Plateau. J. Comput. 7, 1927-1934.

Ishikawa, M., 2003. Thermal regimes at the snow-ground interface and their implications for permafrost investigation. Geomorphology 52, 105-120.

Janke, J.R., Williams, M.W., Evans Jr., A., 2012. A comparison of permafrost prediction models along a section of Trail Ridge Road, Rocky Mountain National Park, Colorado, USA. Geomorphology 138, 111-120.

Keller, R.A., Fisk, M.R., White, W.M., Birkenmajer, K., 1991. Isotopic and trace element constraints on mixing and melting models of marginal basin volcanism, Bransfield Strait, Antarctica. Earth Planet. Sci. Lett. 111, 287-303.

Kellerer-Pirklbauer, A., 2007. A global perspective on active volcanoes and permafrost. Eur. Geosci. Union Vienna 9, 09205

King, J.C., Turner, J., 1997. Antarctic Meteorology and Climatology. Cambridge Atmospheric and Space Science Series. Cambridge University Press, Cambridge, p. 409.

Kneisel, C., Hauck, C., 2008. Electrical methods. In: Hauck, C., Kneisel, C. (Eds.), Applied Geophysics in Periglacial Environments. Cambridge University Press, Cambridge, pp. 3-56.

Lewkowicz, A., 2008. Evaluation of miniature temperature-loggers to monitor snowpack evolution at mountain permafrost sites, Northwestern Canada. Permafr. Periglac. Process. 19, 323-331.

Loke, M.H., Barker, R.D., 1995. Least-squares deconvolution of apparent resistivity. Geophysics 60, 1682-1690.

Lowrie, W., 2007. Fundamentals of Geophysics. Cambridge University Press, Cambridge (393 pp.)

Maestro, A., Somoza, L., Rey, J., Martínez-Frías, J., López-Martínez, J., 2007. Active tectonics, fault patterns, and stress field of Deception Island: a response to oblique convergence between the Pacific and Antarctic plates. J. S. Am. Earth Sci. 23, 256-268.

Martí, J. Vila, J. Rey J. 1996. Deception Island (Bransfield Strait, Antarctica) an example of volcanic caldera developed by extensional tectonics. In: McGuiere, W.C., Jones, A.P., Neuberg, J. (Eds.), Volcano Instability on the Earth and Other Planets. Geological Society London, London, Special Publication, 110, pp. 253-265.

Oht, M., 2003. Impact of meteorological factors on active layer development in Central Spitsbergen. In: Phillips, M., Springman, S., Arenson, L. (Eds.), Permafrost, Proceedings of the 8th International Conference on Permafrost, Zurich, pp. 845-850.

Rakusa-Susczewski, S., Mietus, M. Piasecki, J., 1993. Weather and climate. In: Rakusa-Susczewski, S. (Ed.), The Maritime Antarctic Coastal Ecosystem of Admiralty Bay, Department of Antarctic Biology. Polish Academy of Sciences, Warsaw, pp. 19-25.

Ramos, M., Ortiz, R., Diez-Gil, J.L., Viramonte, J.G., 1989. Anomalías Térmicas y Balance del Flujo disipado en la Isla Decepción. Shetlands del Sur. III Simposio de Estudios Antárticos, CICYT, Madrid, España (pp. 203-219).

Ramos, M., de Pablo, M.A., Sebastian, E. Armiens, C., Gómez-Elvira, J., 2012. Temperature gradient distribution in permafrost active layer, using a prototype of the ground temperature sensor (REMS-MSL) on Deception Island (Antarctica). Cold Reg. Sci. Technol. $72,23-32$.

Rey, J., Somoza, L., Martinez-Frías, J., 1995. Tectonic, volcanic, and hydrothermal event sequence on Deception Island (Antarctica). Geo-Mar. Lett. 15, 1-8.

Rey, J., Somoza, L., Martínez-Frías, J., Benito, R., Martín-Alfageme, S., 1997. Deception Island (Antarctica) a new target for exploration of Fe-Mn mineralization? In: Nicholson, K., Hein, J.R., Buhn, B., Dasgupta, S. (Eds.), Manganese Mineralization: Geochemistry and Mineralogy of Terrestrial and Marine Deposits. Special Publication, 119. Geological Society London, London, pp. 239-251.

Reynolds, J.M., 1997. An Introduction to Applied and Environmental Geophysics. John Wiley and Sons Ltd, Chichester, p. 800.

Roobol, M.J., 1972. Historic volcanic activity at Deception Island, South Shetland Islands. Brit. Antarct. Surv. Bull 32, 23-30.

Roobol, M.J., 1982. The volcanic hazard at Deception Island, South Shetland Islands. Brit. Antarct. Surv. Bull 51, 237-245.

Serrano, E., López-Martínez, J., 2000. Rock glaciers in the South Shetland Islands, Western Antarctica. Geomorphology 35, 145-162.

Shi, G., 2014. Chapter 8-Kriging. Data Mining and Knowledge Discovery for Geoscientists. Elsevier, San Diego, pp. 238-274.

Simonov, I.M., 1977. Physical geographic description of Fildes Peninsula (South Shetland Islands). Polar Geography 1, 223-242.

Smellie, J.L., Chapman, M.G., 2002. Introduction: Volcano-Ice Interaction on Earth and Mars. In: Smellie, J.L., Chapman, M.G. (Eds.), Volcano-Ice Interaction on Earth and Mars. Special Publications, 202. Geological Society of London, London, pp. 1-4

Smellie, J.L., López-Martínez, J., 2000. Geological map of Deception Island. In: Smellie, J.L., López-Martínez, J., Serrano, E., Rey, J. (Eds.), Geology and Geomorphology of Deception Island, Sheet 6-A, 1:25.000. BAS GEOMAP Series. British Antarctic Survey, Cambridge.

Styszynska, A., 2004. The origin of coreless winters in the South Shetlands area (Antarctica). Pol. Polar Res. 25, 45-66.

Telford, W.M., Geldart, L.P., Sheriff, R.E., 1990. Applied Geophysics. Cambridge University Press, Cambridge (760 pp.).

Tormey, D., 2010. Managing the effects of accelerated glacial melting on volcanic collapse and debris flows: Planchon-Peteroa Volcano, Southern Andes. Glob. Planet. Chang. 74, $82-90$.

Torrecillas, C., Berrocoso, M., Pérez-López, R., Torrecillas, M.D., 2012. Determination of volumetric variations and coastal changes due to historical volcanic eruptions using historical maps and remote-sensing at Deception Island (West-Antarctica). Geomorphology 136, 6-14.

Turner, J., Colwell, S.R., Marshall, G.J., Lachlan-Cope, T.A., Carleton, A.M., Jones, P.D., Lagun, V., Reid, P.A., Iagovkina, S., 2005. Antarctic climate change during the last 50 years. Int. J. Climatol. 25, 2279-2294. 
Turner, J., Overland, J.E., Walsh, J.E., 2007. An Arctic and Antarctic perspective on recent climate change. Int. J. Climatol. 27, 277-293.

Urish, D.W., Frohlich, R.K., 1990. Surface electrical resistivity in coastal groundwater exploration. Geoexploration 26, 267-289.

Van Loon, H., 1967. The half-yearly oscillations in middle and high southern latitudes and the coreless winter. J. Atmos. Sci. 24, 472-486.

Vieira, G., López-Martínez, J., Serrano, E., Ramos, M., Gruber, S., Hauck, C., Blanco, J., 2008. Geomorphological Observations of Permafrost and Ground-Ice Degradation on Deception and Livingston Islands, Maritime Antarctica. In: Kane, D.L., Hinkel, K.M. (Eds.), Proceedings Ninth International Conference on Permafrost. , 1. Institute of Northern Engineering, University of Alaska, Fairbanks, Alaska, pp. 655-661.

Vieira, G., Bockheim, J., Guglielmin, M., Balks, M., Abramov, A., Boelhouwers, J., Cannone, N., Ganzert, L., Gilichinsky, D., Goryachkin, D., López-Martınez, J., Meiklejohn, I., Raffi, R., Ramos, M., Schaefer, C., Serrano, S., Simas, F., Sletten, R., Wagner, D., 2010.
Thermal state of permafrost and active-layer monitoring in the Antarctic: advances during the international polar year 2007-2009. Permafr. Periglac. Process. 21, 182-197.

Villegas, M.T., Caselli, A.T., 1995. Fumarolas de Decepción: Evolución a lo largo del Verano Austral. In: Cacho, J., Serrat, D. (Eds.), Actas del V Simposio Español de Estudios Antárticos, Madrid, pp. 235-242.

Walvoort, D.J.J., Gruijter, J.J., 2001. Compositional kriging: a spatial interpolation method for compositional data. Math. Geol. 33, 951-966.

Wardman, J.B., Wilson, T.M., Bodger, P.S., Cole, J.W., Johnston, D.M., 2012. Investigating the electrical conductivity of volcanic ash and its effect on HV power systems. Phys Chem. Earth A/B/C 45-46, 128-145. 